\title{
ANALISIS PENGEMBANGAN KELAPA OLAHAN DI KECAMATAN MAWASANGKA KABUPATEN BUTON TENGAH
}

\author{
Wa Ode Dian Purnamasari \\ Program Studi Agribisnis, Fakultas Pertanian \\ Universitas Muhammadiyah Buton \\ Jln. Betoambari, No. 36 Baubau \\ e-mail: waodedianpurnamasariumb@gmail.com
}

\begin{abstract}
This study aims to analyze development of processed coconut based on financial feasibility aspect and additional value of development processed coconut. This study is conducted at Mawasangka subdistrict, Central Buton Regency. In drawing the total of respondent, it is drawn with Slovin formula as many 55 respondents from 122. The result of this study shows that development of processed coconut at Mawasangka subdistrict, Central Buton Regency to copra production business and shell charcoal was declared viable based on financial analysis obtained $R / C$ ratio in amount 1,67 for copra and shell charcoal get value in amount 5,47. the cultivation of coconut to copra and shell charcoal is done for 3-4 times production in a year. Based on the result, it is suggested that quality and volume of cultivation of processed coconut in Mawasangka subdistrict highly needs to be increased in order to be able to compete in global market. Promotion of cultivation of processed coconut in Mawasangka subdistrict also still needs to be increased in order that the market can be more exposed and increase total of customers to overcome the poor management and limited capital.
\end{abstract}

Keywords: feasibility analysis, processed coconut

\begin{abstract}
Abstrak
Penelitian ini bertujuan untuk menganalisis pengembangan kelapa olahan di Kecamatan Mawasangka Kabupaten Buton berdasarkan aspek kelayakan finansial. Penelitian ini dilaksanakan di Kecamatan Mawasangka Kabupaten Buton Tengah. Penentuan jumlah responden ditentukan dengan rumus slovin sebanyak 55 responden dari 122 orang. Hasil penelitian menunjukan bahwa pengembangan kelapa olahan di Kecamatan Mawasangka Kabupaten Buton Tengah pada olahan usaha produksi kopra dan arang tempurung dinyatakan layak berdasarkan hasil analisis finansial diperoleh nilai $\mathrm{R} / \mathrm{C}$ ratio sebesar 1,67 untuk olahan kopra dan arang tempurung sebesar 5,47. Pengolahan kelapa menjadi kopra dan arang tempurung melakukan 3-4 kali proses produksi selama setahun. Berdasarkan hasil penelitian disarankan kualitas dan volume produksi kelapa olahan Kecamatan Mawasangka sangat perlu ditingkatkan agar mampu bersaing di pasar global. Promosi hasil produksi kelapa olahan di Kecamatan Mawasangka juga masih perlu ditingkatkan agar pasar dapat lebih diperluas dan semakin banyak konsumen yang terjaring. Untuk mengatasi manajemen yang kurang baik dan keterbatasan modal.
\end{abstract}

Kata Kunci: Analisis Kelayakan, kelapa olahan 


\section{PENDAHULUAN}

Indonesia dikenal sebagai negara agraris yang kehidupan perekonomiannya mengandalkan sektor pertanian baik sebagai mata pencaharian maupun sebagai penyedia bahan pangan bagi seluruh masyarakat, serta menopang pertumbuhan industri dalam hal penyediaan bahan baku industri. Sektor pertanian mempunyai kontribusi besar terhadap perekonomian nasional. Selain itu, peranan sektor pertanian yang besar terutama dalam penyediaan lapangan kerja, pendapatan dari ekspor dan sumber pertumbuhan ekonomi (Patty, 2011).

Tanaman kelapa (Cocos nucifera) merupakan tanaman utama dan hampir merata terdapat di seluruh provinsi dan kabupaten di Indonesia. Kelapa memiliki peran strategis bagi masyarakat Indonesia, baik ditinjau dari aspek ekonomi maupun sosial budaya. Peran strategis itu terlihat dari total luas perkebunan kelapa di Indonesia yang mencapai 3.712 juta hektar $(31,4 \%)$ dan merupakan luas areal perkebunan kelapa terbesar di dunia. Produksi kelapa di Indonesia menempati urutan kedua di dunia yakni sebesar 12.915 milyar butir atau 24,4\% produksi dunia (BPS, 2016).

Kelapa telah berada di Indonesia sejak ribuan tahun lalu, dan menjadi salah satu penopang ekonomi rakyat karena semua materi dari kelapa dapat dimanfaatkan. Manfaat tanaman kelapa tidak saja terletak pada daging buahnya yang dapat diolah menjadi santan, kopra, dan minyak kelapa, tetapi seluruh bagian tanaman kelapa mempunyai manfaat yang besar seperti tempurung kelapa dimanfaatkan menjadi arang tempurung.Tanaman kelapa juga sebagai sumber pendapatan bagi keluarga petani, sebagai sumber devisa negara, penyedia lapangan kerja, pemicu dan pemacu pertumbuhan sentra-sentra ekonomi baru, serta sebagai pendorong tumbuh dan berkembangnya industri hilir berbasis minyak kelapa dan produk ikutannya di Indonesia. Namun kenyataannya di tingkat petani pemanfaatan masih dalam bentuk produk primer berupa kelapa butiran dan kopra yang diolah secara tradisional. Hal ini dikarenakan berbagai macam kendala terutama keterbatasan wawasan petani, teknologi, permodalan, industri hilir yang belum berkembang, dan daya serap pasar yang belum merata.

Kabupaten Buton Tengah Provinsi Sulawesi Tenggara, kelapa merupakan salah satu komoditi perkebunan yang banyak diminati oleh masyarakat petani setelah tanaman jambu mete. Hal ini dikarenakan kelapa merupakan pohon yang serba guna dan mempunyai nilai ekonomis.

Pengolahan kelapa menjadi kopradan arang tempurung masih secara tradisional dan masih menggunakan peralatan manual seperti parang, alat pencungkil sabut kelapa, tempat pengasapan kopra, dan drum untuk pembakaran arang tempurung.Pengolahan kelapa ini juga masih sangat tradisonal sehingga mengakibatkan waktu produksi yang lama. Dalam memperoleh bahan baku, pengolah kelapa membeli dan mengolah kelapanya sendiri. Bahan baku ini dibeli dengan kisaran harga Rp 1.000 sampai dengan Rp. 2.000 per buah. Untuk $1 \mathrm{~kg}$ kopra membutuhkan buah kelapa sebanyak 2 buah kelapa. Dimana dalam satu kali pengolahan (setiap 3 bulan) membutuhkan sekitar 500-2000 buah kelapa, yang menghasilkan 125-500 kg kopra Sementara untuk arang tempurung, dalam $1 \mathrm{~kg}$ membutuhkan 14 buah kelapa dan dalam satu kali pengolahannya membutuhkan 500-2000 buah kelapa menghasilkan 35-143 kg arang tempurung. Berbagai kendala yang dihadapi petani pengolah kelapa di lokasi ini, masih merupakan masalah klasik seperti yang terjadi di daerah-daerah lain di Indonesia.

Adapun tujuan dari penelitian ini untuk menganalisis pengembangan kelapa olahan di Kecamatan Mawasangka Kabupaten Buton Tengah berdasarkan aspek kelayakan finansial. 


\section{TINJAUAN PUSTAKA}

\section{Kelayakan Finansial}

Analisis finansial berkepentingan terhadap penerimaan (revenue) yang akan diperoleh dari proyek. Analisis finansial juga penting bagi pihak luar terutama bagi lembaga-lembaga keuangan yang memberikan pinjaman. Aspek finansial terutama menyangkut perbandingan antara pengeluaran dan pendapatan (revenue earnings) dari proyek, serta waktu didapatkannya hasil (returns). Untuk mengetahui secara komprehensif tentang kinerja layak atau tidaknya suatu aktivitas proyek maka dikembangkan berbagai kriteria yang pada dasarnya membandingkan antara biaya dan manfaat atas dasar suatu tingkat harga umum tetap yang diperoleh proyek dengan menggunakan nilai sekarang (present value) yang telah didiskon selama umur proyek tersebut (Kunarjo, 2002).

Analisis kelayakan finansial adalaha landasan untuk menentukan sumber daya finansial yang diperlukan untuk tingkat kegiatan tertentu dan laba yang bisa diharapkan. Kebutuhan finansial dan peengembalian (return) bisa sangat berbeda tergantung pada pemilihan alternatif yang ada bagi sebagian besar usaha.

Analisis Revenue Cost Ratio (R/C ratio) digunakan untuk mengetahui nilai efisiensi pendapatan pengolahan kelapa menjadi kopra dan arang tempurung sehingga dapat diketahui tingkat kelayakan dari pengolahan kelapa yang dilakasanakan dengan kriteria jika nilai $\mathrm{R} / \mathrm{C}$ ratio > 1 maka pengolahan kelapa menjadi kopra dan arang tempurung layak untuk dikembangkan, jika nilai $\mathrm{R} / \mathrm{C}$ ratio $<1$ maka pengolahan kelapa menjadi kopra dan arang tempurung tidak layak untuk dikembangkan dan jika nilai $\mathrm{R} / \mathrm{C}$ ratio $=1$ maka pengolahan kelapa menjadi kopra dan arang tempurung dikatakan impas atau balik modal (Husnan dan Suwarsono, 2000).

$$
R / C \text { Ratio }=\frac{T R}{T C}
$$

Keterangan:

$\mathrm{R} / \mathrm{C}$ Ratio = Revenue Cost Ratio.

$\mathrm{TR}=$ Total Revenue (penerimaan kotor budidaya ikan kerapu).

$\mathrm{TC}=$ Total Cost (jumlah keseluruhan biaya yang harus dikeluarkan oleh pembudidaya ikan kerapu sebagai konsekuensi penggunaan input produksi).

\section{METODE PENELITIAN}

\section{Lokasi dan Waktu Penelitian}

Penelitian ini dilaksanakan di Kecamatan Mawasangka Kabupaten Buton Tengah. Lokasi penelitian ditentukan secara purposive, dengan pertimbangan bahwa di Kecamatan Mawasangka merupakan daerah yang memiliki luas lahan dan produksi kelapa tertinggi, dibandingkan dengan wilayah lainnya, serta mampu mengolah kelapa dalam bentuk kopra dan arang tempurung. Potensi pengembangan kelapa di Kecamatan Mawasangka tersebar pada 1 kelurahan dan 3 desa yaitu Kelurahan Mawasangka, Desa Oengkalaki, Desa Balobone dan Desa Napa. Berdasarkan informasi dari petugas penyuluh pertanian Kecamatan Mawasangka, diketahui bahwa hanya pada desa dan kelurahan tersebutlah yang rutin melakukan pengolahan kopra. Penelitian dilaksanakan pada Bulan Oktober tahun 2016 sampai Bulan September tahun 2017. 


\section{Populasi dan Teknik Penentuan Sampel}

Populasi dalam penelitian ini adalah penduduk yang melakukan usaha pengolahan produk kelapa yaitu kopra dan arang tempurung di Kecamatan Mawasangka, yang tersebar pada satu kelurahan dan tiga desa, yaitu Kelurahan Mawasangka, Desa Oengkolaki, Desa Nepa, dan Desa Balobone, sehingga ke empat lokasi tersebut akan dijadikan lokasi penelitian dengan jumlah populasi sebanyak 122 orang. Penentuan jumlah responden ditentukan dengan rumus Slovin (Sugiyono, 2012). Pemilihan jumlah sampel dilakukan secara simple random sampling (secara acak sederhana) dan penentuan sampel disetiap lokasi penelitian ditentukan secara proporsional. berikut:

Penentuan jumlah responden, digunakan rumus Slovin (Sugiyono, 2012) adalah sebagai

$$
n=\frac{N}{1+N\left(\alpha^{2}\right)}=\frac{122}{1+122\left(0,1^{2}\right)} \quad=\frac{122}{2,22}=55
$$

Keterangan;

$$
\begin{array}{ll}
n & =\text { Jumlah ukuran sampel (orang) } \\
N & =\text { Jumlah populasi (orang) } \\
\alpha & =\text { Derajat kesalahan }(10 \%)
\end{array}
$$

\section{Teknik Analisa Data}

Dalam menentukan kelayakan pengembangan usaha pengolahan produk kelapa olahan dilakukan secara analisis kelayakan finansial terhadap usaha kopra dan arang tempurung yang merupakan kajian keuangan untuk mengetahui keberhasilan dan penerimaan yang telah dicapai selama usaha kelapa olahan menjadi kopra dan arang tempurung tersebut berlangsung. Dengan analisis ini, pengolah kelapa dapat membuat perhitungan dan menentukan tindakan apa yang untuk memperbaiki dan meningkatkan keuntungan dalam usahanya.

Analisis Revenue Cost Ratio (R/C ratio) digunakan untuk mengetahui nilai efisiensi pendapatan pengolahan kelapa menjadi kopra dan arang tempurung sehingga dapat diketahui tingkat kelayakan dari pengolahan kelapa yang dilakasanakan dengan kriteria jika nilai $\mathrm{R} / \mathrm{C}$ ratio $>1$ maka pengolahan kelapa menjadi kopra dan arang tempurung layak untuk dikembangkan, jika nilai $\mathrm{R} / \mathrm{C}$ ratio $<1$ maka pengolahan kelapa menjadi kopra dan arang tempurung tidak layak untuk dikembangkan dan jika nilai $\mathrm{R} / \mathrm{C}$ ratio $=1$ maka pengolahan kelapa menjadi kopra dan arang tempurung dikatakan impas atau balik modal (Husnan dan Suwarsono, 2000).

$$
R / C \text { Ratio }=\frac{T R}{T C}
$$

Keterangan:

$\mathrm{R} / \mathrm{C}$ Ratio = Revenue Cost Ratio.

$\mathrm{TR}=$ Total Revenue (penerimaan kotor budidaya ikan kerapu).

$\mathrm{TC}=$ Total Cost (jumlah keseluruhan biaya yang harus dikeluarkan oleh pembudidaya ikan kerapu sebagai konsekuensi penggunaan input produksi). 


\section{HASIL DAN PEMBAHASAN}

\section{Teknis Produksi Kelapa Olahan}

Usaha kelapa olahan di Kecamatan Mawasangka telah dilakukan secara turun temurun. Hal ini ditunjukkan dengan pengalaman usaha dari pengolah kelapa yang sudah cukup lama berkisar kurang lebih 15-20 tahunan. Teknis pengolahan kelapa menjadi kopra dan arang tempurung di Kecamatan Mawasangka masih bersifat tradisional tanpa menggunakan teknologi mesin dan bersifat padat karya. Produksi kelapa olahan dilakukan rata-rata empat kali dalam satu tahun tergantung ketersediaan bahan baku utama. Adapun teknis produksi kelapa olahan di Kecamatan Mawasangka terbagi atas dua yaitu teknis produksi kopra dan teknis produksi arang tempurung.

Teknis produksi kopra meliputi pengumpulan kelapa, pengupasan sabut, pembelahan buah kelapa, pencungkilan, pengeringan dan pengemasan yang dijelaskan sebagai berikut :

a) Pengumpulan kelapa

Kegiatan mengumpulkan kelapa sebagai bahan baku utama dalam produksi kelapa olahan di Kecamatan Mawasangka terdiri dari mengumpulkan dari hasil kebun kelapa sendiri dan membeli dari petani kelapa. Kelapa yang digunakan dalam proses pengolahan kopra adalah kelapa tua karena kelapa tua memiliki kadar minyak yang tinggi, yang sangat dibutuhkan untuk kepentingan industri. Kelapa tua ditandai dengan sabut yang mulai mengering, tempurung yang sudah berwarna hitam, air kelapa sedikit dan bila diguncang berbunyi. Berat buah kelapa yang digunakan rata-rata $1 \mathrm{~kg}$ perbuah. Bahan baku utama dalam satu kali produksi rata-rata 2000 buah kelapa yang akan digunakan dalam produksi kopra dan juga arang tempurung. Jika kelapa diambil atau dibeli dari pengumpul kelapa maka harga kelapa perbuahnya Rp. 1500. Pengumpulan buah kelapa dilakukan di tempat produksi.

b) Pengupasan Sabut Kelapa

Pengupasan sabut kelapa dalam jumlah banyak dilakukan masyarakat dengan menggunakan alat tradisional pengupas kelapa yang berbentuk linggis terbuat dari besi ataupun kayu yang dipasang berdiri vertikal dengan matanya mengarah keatas, setinggi $\pm 80 \mathrm{~cm}$ diatas tanah Pengupasan Kelapa dengan cara tradisional ini harus benar-benar berpengalaman dan memiliki tingkat ketelitian yang tinggi. Sabut hasil pengupasan kelapa tersebut dikumpulkan kemudian digunakan untuk mengasapi.

c) Pembelahan buah kelapa

Pembelahan buah kelapa bertujuan untuk membuang air kelapa yang tidak dipakai dalam proses pengolahan kopra serta untuk mempermudah kegiatan pencungkilan daging buah kelapa. Kegiatan pembelahan ini menggunakan alat berupa parang.

d) Pengasapan

Pengapasan dilakukan dengan cara daging kelapa yang sudah dibela dimasukan kedalam rumah pengasapan dengan membakar sabut kelapa dibawah rumah pengapasan. Pengasapan membutuhkan waktu 3 hari.

e) Pencungkilan

Pencungkilan daging buah kelapa dilakukan untuk memisahkan daging buah kelapa yang melekat pada tempurung kelapa. Alat yang digunakan dalam proses ini berupa pencungkil. Setelah dicungkil kelapa kembali diasapi sampai 4-5 hari sehingga mendapatkan kopra kering.

f) Pengemasan

Sebelum dikemas kopra dipotong kecil-kecil. Pengemasan kopra dilakukan untuk mempermudah perhitungan berat kopra dan juga untuk mempermudah proses 
pengangkutan. Kopra dikemas dalam karung goni berkapasitas $50 \mathrm{~kg}$ dan $100 \mathrm{~kg}$. Pengemasan kopra rata-rata menghasilkan 10 karung atau $1.000 \mathrm{~kg}$.

Sementara untuk teknis produksi arang tempurung meliputi pengumpulan batok kelapa, pembakaran dan pengemasan yang dijelaskan sebagai berikut :

a) Pengumpulan batok kelapa

Dalam produksi arang tempurung menggunakan bahan baku utama yang diambil dari bahan baku utama produksi kopra. Pengumpulan batok kelapa dilakukan disaat pencungkilan buah kelapa yang memisahkan antara daging buah kelapa dan batok kelapa. Dari berat $1 \mathrm{~kg}$ kelapa dapat menghasilkan 250 gram berat batok kelapa. Batok kelapa ini dikumpulkan langsung didekat tempat pembakaran tanpa menghitung berat awal.

b) Pembakaran

Pembakaran batok kelapa menggunakan teknik pembakaran kiln drom yaitu pembakaran dengan menggunakan drom bekas yang dapat diisi 90-100 kg batok kelapa. Masukan tempurung satu demi satu sambil ditata agar dapat terbakar dengan sempurna. Penataan tempurung dilakukan dengan meletakkn kayu atau batang bambu pada bagian tengah drum, selanjutnya tempurung diatur hingga memenuhi drum. Setelah penuh, kayu atau bambu tersebut dicabut secara perlahan-lahan sehingga bagian tengah bekas bambu tersebut berbentuk lubang. Lubang tersebut nantinya akan digunakan untuk pembakaran. Kemudian diberi sedikit minyak tanah lalu dibakar. Setelah proses pembakaran berlangsung tempurung kelapa dimasukkan lagi sedikit demi sedikit hingga penuh. Selama proses pembakaran berlangsung senantiasa diawasi agar pembakaran sempurna yaitu tempurung kelapa terbakar secara merata. Pembakaran dilakukan selama kurang lebih 5-7 jam.

c) Pendinginan

Proses pendinginan dilakukan dengan menyiram tempurung yang telah terbakar dengan air sedikit demi sedikit sehingga berubah menjadi arang dan apinya sudah padam. Penyiram seperti ini harus dilakukan tepat waktu untuk mencegah agar arang tidak menjadi abu, dan untuk menjaga kualitas arang yang dihasilkan. Selanjutnya proses pendinginan dengan cara menutup drom pembakaran menggunakan karung goni selama 2 jam. Kemudian tutup kiln drom dapat dibuka dan arang dikeluarkan untuk dipisahkan

d) Pengemasan

Proses pengemasan dilakukan dengan memasukan arang tempurung kedalam karung plastik yang telah disiapkan. Besarnya kemasan yang digunakan adalah rata-rata $50 \mathrm{~kg}$.

\section{Pemasaran Produksi Kelapa Olahan}

Analisis pemasaran produksi kelapa olahan di Kecamatan Mawasangka meliputi kondisi permintaan dan penawaran pasar, harga, saluran pemasaran, strategi pemasaran, dan persaingan usaha.

1. PermintaandanPenawaranPasar

Permintaan produksi kelapa olahan dalam hal ini kopra dan arang tempurung tergantung pada aktivitas dan produktivitas industri yang berada di Kabupaten Buton Tengah dan sekitarnya. Peluang permintaan sebenarnya lebih besar apabila kopra dan arang tempurung tersebut dipasarkan ke berbagai industri besar di Kendari, Makassar dan berbagai daerah lainnya.

Produksi kelapa olahan di Kecamatan Mawasangka menunjukkan nilai yang cukup baik dengan hasil produksi dalam satu kali produksi masing-masing sebesar $\pm 1,2$ ton untuk kopra terdapat pada Lampiran 2 dan sebesar $\pm 350 \mathrm{~kg}$ untuk arang pada tahun 2016 terlihat pada Lampiran 3. Dengan hasil produksi dalam pengolah kelapa belum mampu memenuhi 
permintaan pasar dari kota-kota besar ataupun permintaan ekspor dari negara-negara yang banyak menggunakan kopra dan arang tempurung. Kendala yang dihadapi pengolah kelapa dalam mengelola usahanya yaitu sulitnya memperoleh bahan baku utama dalam kuantitas dan rendahnya kualitas hasil produksi yang memenuhi syarat sehingga permintaan akan jenis ini belum maksimal dikarenakan produksi yang masih menggunakan cara tradisional tanpa menggunakan teknologi mesin.

2. Harga

Berdasarkan hasil wawancara, harga yang berlaku di lokasi pengolahan kelapa fluktuatif, ini dikarenakan ada saat-saat tertentu harga kelapa olahan menunjukan harga yang cenderung naik

3. SaluranPemasaran

Saluran pemasaran yaitu jalur atau proses pemasaran yang menghubungkan dari produsen hingga konsumen. Saluran pemasaran juga dapat mempengaruhi harga suatu produk. Dari hasil penelitian hanya terdapat dua macam saluran pemasaran produksi kopra dan arang tempurung yang ada di Kecamatan Mawasangka yaitu : (1) saluran pemasaran kopra dan arang tempurung di Kecamatan Mawasangka dimana petani kelapa menjual kelapa butiran kepada pengolah kelapa olahan. Pengolah tidak memiliki kelapa atau kebutuhan bahan bakunya kurang sehingga harus membeli kelapa butiran dari petani kelapa yang kemudian kelapa tersebut diolah menjadi kopra dan arang tempurung. kemudian di jual kepada pengumpul besar dan kemudian dari pengumpul besar ke pabrik yang membutuhkan. (2) saluran pemasaran kopra dan arang tempurung di Kecamatan Mawasangka yang kedua tidak berbeda jauh dengan saluran pemasaran yang pertama bedanya petani langsung mengolah hasil panen kelapanya menjadi kopra dan arang tempurung, yang kemudian langsung di jual ke pedagang besar dan kemudian dari pengumpul pedagang besar dijual ke pabrik yang membutuhkan. Pemasaran kelapa olahan menjadi kopra dan arang tempurung di Kecamatan Mawasangka dilakukan ditempat produksinya karena pembeli langsung datang ketempat pengolahan dengan harga Rp. 10.500 untuk kopra dan Rp. 3000 untuk arang tempurung.

\section{Kelayakan Finansial Produksi Kelapa Olahan}

\section{Biaya Produksi}

Biaya produksi adalah akumulasi dari semua biaya-biaya yang dibutuhkan dalam proses produksi suatu usaha yang akan menghasilkan suatu produk. Biaya produksi yang dikeluarkan oleh pengolah kelapa selama produksi meliputi biaya tetap dan biaya variabel. Biaya tetap adalah biaya yang jumlahnya tetap, tidak tergantung kepada perubahan tingkat kegiatan dalam menghasilkan produk. Biaya variabel adalah biaya yang sifatnya tergantung pada jumlah produksi yang dihasilkan. Biaya tetap pada usaha pengolahan kelapa menjadi kopra dan arang tempurung di Kecamatan Mawasangka meliputi biaya penyusutan alat yang dapat disajikan pada Tabel 1 dan Tabel 2.

Tabel 1. Penggunaan Biaya Tetap pada Usaha Kopra di Kecamatan Mawasangka, Tahun 2016

\begin{tabular}{|c|c|c|}
\hline No & Alat & Rata-Rata Penyusutan (Rp) \\
\hline 1 & Parang & 28.095 \\
\hline 2 & Linggis & 20.291 \\
\hline 3 & Pencungkil & 4.418 \\
\hline & Jumlah & 52.804 \\
\hline
\end{tabular}


Berdasarkan Tabel 1 besarnya rata-rata total biaya tetap yang dikeluarkan pengolah kopra sebesar Rp. 52.804. Dari ketiga alat yang merupakan total biaya tetap terbesar dikeluarkan pada alat parang sebesar Rp. 28.095 dari jumlah rata-rata total biaya tetap, sedangkan biaya terkecil yang dikeluarkan pada alat pencungkil sebesar Rp.4.418.

Tabel 2. Penggunaan Biaya Tetap pada Usaha Arang Tempurung di Kecamatan Mawasangka, Tahun 2016

\begin{tabular}{clr}
\hline \multirow{2}{*}{ No } & \multirow{2}{*}{ Alat } & \multicolumn{2}{c}{$\begin{array}{c}\text { Rata-Rata Penyusutan } \\
(\mathrm{Rp})\end{array}$} \\
\hline 1 & Drom & 40.364 \\
\hline 2 & Karung Goni & 12.909 \\
\hline & Jumlah & 53.273 \\
\hline
\end{tabular}

Berdasarkan Tabel 2. besarnya rata-rata total biaya tetap yang dikeluarkan pengolah arang tempurung sebesar Rp.53.273. Dari kedua alat yang merupakan total biaya tetap terbesar dikeluarkan pada alat drom sebesar Rp.40.364 dari jumlah rata-rata total biaya tetap, sedangkan biaya terkecil yang dikeluarkan pada karung goni sebesar Rp.12.909.

Biaya variabel adalah biaya yang dikeluarkan tergantung pada volume produksi. Biaya variabel pada usaha kopra meliputi harga beli bahan baku dan tenaga kerja. Rata-rata biaya variabel yang dikeluarkan pada usaha kopra sebesar Rp.8.057.272. Rata-rata biaya variabel pembelian bahan baku yang dikeluarkan pengolah kopra sebesar Rp.7.759.090 dari rata-rata total biaya variabel dan biaya tenaga kerja pengolah kopra sebesar Rp. 298.182 dari rata-rata total biaya variabel, lebih jelasnya dapat dilihat pada Tabel 3.

Tabel 3. Penggunaan Biaya Variabel pada Usaha Kopra di Kecamatan Mawasangka, Tahun 2016

\begin{tabular}{clr}
\hline No. & \multicolumn{1}{c}{ Biaya } & \multicolumn{2}{c}{ Rata-rata (Rp) } \\
\hline 1 & Bahan baku & 7.759 .090 \\
\hline 2 & Tenaga Kerja & 298.182 \\
\hline Jumlah & 8.057 .272 &
\end{tabular}

Biaya variabel pada usaha arang tempurung meliputi biaya tenaga kerja Rata-rata biaya variabel yang dikeluarkan pada usaha arang tempurung sebesar Rp.149.091, lebih jelasnya dapat dilihat pada Tabel 4.

Tabel 4. Penggunaan Biaya Variabel pada Usaha Arang Tempurung di Kecamatan Mawasangka, Tahun 2016

\begin{tabular}{|c|c|c|}
\hline No. & Biaya & Rata-rata (Rp) \\
\hline 1 & Tenaga Kerja & 149.091 \\
\hline Jumlah & 149.091 & \\
\hline
\end{tabular}

Rata-rata total biaya yang dikeluarkan pada usaha kopra sebesar Rp. 8.110.076 lebih jelasnya dapat melihat Tabel 5.

Tabel 5. Biaya Usaha Kopra di Kecamatan Mawasangka, Tahun 2016

\begin{tabular}{ll}
\hline No. $\quad$ Uraian & Rata-Rata Jumlah (Rp) \\
\hline
\end{tabular}




\begin{tabular}{llr}
\hline 1 & Biaya tetap & 52.804 \\
\hline 2 & Biaya variabel & 8.057 .272 \\
\hline & Total biaya & 8.110 .076 \\
\hline
\end{tabular}

Rata-rata total biaya yang dikeluarkan pada usaha arang tempurung sebesar Rp. 202.364, lebih jelasnya dapat melihat Tabel 6.

Tabel 6. Biaya Usaha Arang Tempurung di Kecamatan Mawasangka, Tahun 2016

\begin{tabular}{clr}
\hline & Uraian (Rata- & \\
No. & rata) & Jumlah $(\mathrm{Rp})$ \\
\hline 1 & Biaya tetap & 53.273 \\
& Biaya & 149.091 \\
2 & variabel & 202.364 \\
\hline & Total biaya & \\
\hline
\end{tabular}

\section{Penerimaan dan Pendapatan}

Penerimaan usaha adalah hasil perkalian antara jumlah produksi dengan harga jual sedangkan pendapatan merupakan selisih antara total penerimaan dengan total biaya. Pendapatan usaha kopra dan arang tempurung diperoleh dari selisih total penerimaan yang diperoleh dengan total biaya yang dikeluarkan dalam satu kali produksi. Rata-rata penerimaan dan pendapatan usaha kopra secara rinci dapat disajikan pada Tabel 7. Dari Tabel 7 diketahui harga kopra yang ada di Kecamatan Mawasangka sebesar Rp. 10.500/kg dengan jumlah produksi rata-rata $1.293 \mathrm{Kg}$. Dengan demikian rata-rata total penerimaan usaha kopra sebesar Rp. 13.578.409 dengan rata-rata pendapatan sebesar Rp 5.364.678.

Tabel 7. Penerimaan dan Pendapatan Usaha kopra di Kecamtan Mawasangka, Tahun 2016

\begin{tabular}{clc}
\hline No & Uraian & Rata-rata nilai \\
\hline 1 & Hasil produksi $(\mathrm{Kg})$ & 1.293 \\
2 & Harga $(\mathrm{Rp})$ & 10.500 \\
3 & Penerimaan $(\mathrm{Rp})$ & 13.578 .409 \\
4 & Pendapatan $(\mathrm{Rp})$ & 5.364 .678 \\
\hline
\end{tabular}

Usaha kopra akan menguntungkan atau dikatakan layak apabila penerimaan yang di peroleh lebih besar dari biaya yang di keluarkan untuk operasional usaha kopra. Sedangkan apabila penerimaan yang diperoleh lebih kecil daripada biaya yang di keluarkan, maka usaha kopra tersebut tidak menguntungkan atau tidak layak. Untuk mengetahui kelayakan usaha kopra di Kecamatan Mawasangka dilakukan dengan menggunakan analisis Revenue Cost Ratio dengan persamaan sebagai berikut :

$$
R / C \text { Ratio }=\frac{13.578 .409}{8.110 .076}=1,67
$$

Dari rincian diatas, dapat disimpulkan bahwa usaha kopra di Kecamatan Mawasangka Kabupaten Buton Tengah layak dusahakan. Berdasarkan hasil RevenueCost Ratio diperoleh nilai sebesar 1,67. Nilai tersebut menunjukan bahwa pengolahan kelapa menjadi kopra di 
Kecamtan Mawasangka layak secara finansial, karena dalam penggunaan 1 rupiah input produksi menghasilkan penerimaan sebesar 1,67 rupiah.

Tabel 8. Penerimaan dan Pendapatan Usaha Arang Tempurung di Kecamtan Mawasangka, Tahun 2016

\begin{tabular}{clc}
\hline No & Uraian & Rata-rata nilai \\
\hline 1 & Hasil produksi $(\mathrm{Kg})$ & 369 \\
2 & Harga (Rp) & 3000 \\
3 & Penerimaan $(\mathrm{Rp})$ & 1.107 .818 \\
4 & Pendapatan $(\mathrm{Rp})$ & 905.455 \\
\hline
\end{tabular}

Rata-rata penerimaan dan pendapatan usaha arang tempurung diketahui harga arang tempurung yang ada di Kecamatan Mawasangka sebesar Rp. 3000/kg dengan jumlah produksi rata-rata $369 \mathrm{Kg}$. Dengan demikian rata-rata total penerimaan usaha arang tempurung sebesar Rp. 1.107.818 dengan rata-rata pendapatan sebesar Rp 905.455.

Usaha arang tempurung akan menguntungkan atau dikatakan layak apabila penerimaan yang di peroleh lebih besar dari biaya yang di keluarkan untuk operasional usaha arang tempurung. Sedangkan apabila penerimaan yang diperoleh lebih kecil daripada biaya yang di keluarkan, maka usaha arang tempurung tersebut tidak menguntungkan atau tidak layak. Untuk mengetahui kelayakan usaha arang tempurung di Kecamatan Mawasangka dilakukan dengan menggunakan analisis Revenue Cost Ratio dengan persamaan sebagai berikut :

$$
R / C \text { Ratio }=\frac{1.107 .818}{202.364}=5,47
$$

Dari rincian diatas, dapat disimpulkan bahwa usaha kopra di Kecamatan Mawasangka Kabupaten Buton Tengah layak dusahakan. Berdasarkan hasil RevenueCost Ratio diperoleh nilai sebesar 5,47. Nilai tersebut menunjukan bahwa pengolahan kelapa menjadi arang di Kecamatan Mawasangka layak secara finansial, karena dalam penggunaan 1 rupiah input produksi menghasilkan penerimaan sebesar 5,47 rupiah.

\section{KESIMPULAN}

Pengembangan kelapa olahan berupa kopra dan arang tempurung dinyatakan layak untuk dikembangkan di Kecamatan Mawasangka Kabupaten buton Tengah, dimana hasil analisis finansial Revenue Cost Ratio diperoleh nilai sebesar 1,67 untuk olahan kopra dan untuk arang tempurung memperoleh nilai sebsar 5,47. Nilai tersebut menunjukan bahwa pengembangan usaha kelapa olahan menjadi kopra dan arang tempurung di Kecamatan Mawasangka layak secara finansial.

\section{SARAN}

Diharapakan pada petani kelapa olahan kopra dan arang tempurung agar menjalin hubungan kerjasama dengan berbagai pihak terutama pada pemerintah setempat dan pemilik modal agar pengembangan kelapa olahan terus meningkat setiap tahunnya. 


\section{DAFTAR PUSTAKA}

BPS. 2016. Statistik Indonesia. Badan Pusat Statistik. Jakarta.

Emilia, Usman. 2014. Karakterisasi Briket Campuran Arang Tempurung Kelapa dan Serbuk Kayu Gergaji Sebagai Bahan Bakar Alternatif Ramah Lingkungan. Universitas Negeri Gorontalo. Gorontalo.

Gitiinger, J.P. 1986. Analisa Ekonomi Proyek-Proyek Pertanian. Universitas Indonesia. Jakarta.

Hernanto, F. 1991. Ilmu Usahatani. Penebar Swadaya. Jakarta.

Husnan, S, dan Suwarsono. 2000. Studi Kelayakan Proyek. Edisi Keempat. UPP AMP YKPN. Yogyakarta.

Hutapea, R. dan C. Indrawanto. 2014. Pengembangan Bioindustri Kelapa Model Kelompok Tani. Prosiding Konferensi Nasional Kelapa VIII. Balai Penelitian Tanaman Palma, Manado.

Ibrahim, M, Y. 2003. Studi Kelayakan Bisnis. Rineka Cipta. Jakarta.

Irawadi, D. 2000. Kontribusi Teknologi Proses Dalam Pembangunan Agroindustri Perkebunan Menuju Otonomi Daerah. Pusat Penelitian dan Pengembangan Tanaman Perkebunan. Jakarta.

Kadariah. 2001. Evaluasi Proyek Analisis Ekonomis. Fakultas Ekonomi Universitas Indonesia. Jakarta.

Kartasapoetra, A.G. 1998. Ekonomi Produksi Pertanian. Bina Aksara. Jakarta.

Kuswanto. 2012. Analisis Kelayakan Finansial Usaha Pengolahan ProdukTurunan Kelapa di Provinsi Jambi. Jurnal Mankeu, 1(3): 209-216.

Patty, Z. 2011. Analisis Produktivitas danNilai Tambah Kelapa Rakyat (Studi Kasus di Tiga Kecamatan 